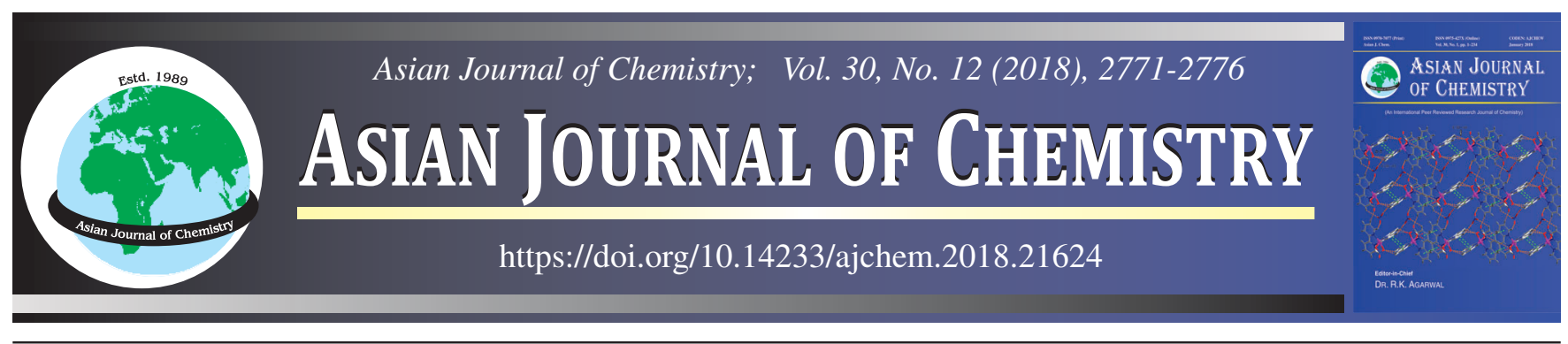

\title{
Chemotype Analysis and Antimicrobial Activities of Essential Oils from Fresh and Sun-Dried Berries of Piper guineense (Schum. and Thom)
}

\section{I.A. Owокотомо ${ }^{1, *}$ and A.V. ChuкwUкA ${ }^{2}$}

${ }^{1}$ Department of Chemistry, Federal University of Technology, P.M.B. 704 Akure, Nigeria

${ }^{2}$ Ecology and Environmental Biology Research Unit, Department of Zoology, University of Ibadan, Ibadan, Nigeria

*Corresponding author: E-mail: adekunleowokotomo@gmail.com

Received: 1 August 2018;

Accepted: 8 October 2018;

Published online: 31 October 2018;

AJC-19146

Chemical constituents of the essential oils obtained through hydrodistillation from fresh and sun-dried berries of Piper guineense were
determined through gas chromatography/flame ionization detection (GC/FID) together with gas chromatography/mass spectrometry
$(\mathrm{GC} / \mathrm{MS})$ techniques. The antimicrobial activities were evaluated through agar diffusion method. The oil yields from the dried berries
$(1.42 \% \mathrm{v} / \mathrm{w})$ was higher than $1.10 \%$ from fresh berries. Chemical profile of oils showed $61 \mathrm{compounds}$ which accounted for $99 \%$ of the
total oils' content. Essential oil from fresh berries consisted mainly of $\alpha$-fellandrene $(26.32 \%), \delta$-3-carene $(16.63 \%)$ and $\beta$-pinene $(9.89$
$\%)$. Dried berries oil was composed of $\beta$-linalool $(11.96 \%), \beta$-pinene $(7.82 \%)$, caryophyllene $(7.65 \%), \alpha$-pinene $(7.11 \%), 3$-carene
$(5.38 \%), \beta$-bisabolene $(5.11 \%)$ and $\beta$-copaene $(4.16 \%)$. The essential oil from dried berries had higher sesquiterpenes while the fresh
berries had more of monoterpene hydrocarbons. The higher sesquiterpene content of oil from dried berries may be attributed to the loss
of monoterpenes through drying, while higher alcohol may be as a result of aerial oxidation of some constituents. Essential oils from dried
berries had a more inhibition effect on Gram-positive bacteria (Staphylococcus aureus), Gram-negative bacteria (Escherichia coli) and
two fungi species: Candida albicans and Aspergillus flavus compared to fresh berries extract. These findings suggest that sun-drying as
preservation method may enhance the antimicrobial activity of Piper guineense.

| Keywords: Essential oils, Chemotype, Antimicrobial activity, Piper guineense.

\section{INTRODUCTION}

Plants derived products have been major means of sustenance for mankind through ages. Plants' volatile components also known essential oils have been used in different applications by man especially as fragrance and in the treatment of diseases. In addition, the bioactivity of essential oils has been explored in food preservation and in medicine, especially in aromatherapy [1-6].

Piper guineensis (Schum. and Thom) commonly known as 'Iyere' in South-west Nigeria is a plant from the family Piperaceae $[7,8]$. The genus, Piper is native to West African sub region [9]. In parts of Nigeria, it is used in traditional medicines and as ingredient in soup preparations $[10,11]$. In some parts of the country, especially among the 'Igbo' speaking population, it is used to enhance quick delivery of new born babies by pregnant women [12,13]. Piper guineense essential oils are also used in traditional medicine for the treatment of skin diseases [14]. The essential oils of numerous Piper species have been reported to possess biological activity against different pathogens $[15,16]$. In general, Piper guineense is known among folks in Southern Nigeria to improve wellness and thus used as additives in many local medicinal preparations.

In previous studies, isolation and characterization of terpene hydrocarbons from Piper guineense essential oil have been undertaken through matching of retention indices, infrared and UV spectra. The components identified were $\delta$-elemene, $\alpha$-copaene, $\beta$-elemene, $\alpha$-cis-bergamotene, $\alpha$-santalene, $\alpha$-transbergamotene, $\beta$-caryophyllene, $\alpha$-humulene, $\beta$-selinene, $\alpha$-selinene, $\beta$-bisabolene, $\delta$-cadinene and calamenene [17]. Okonkwo and Okoye [18] have reported piperine and chavicine while Lale [19] noted the presence of piperidine and alkaloids as the major components in $P$. guineense seeds. Similar studies by Oyedeji et al. [20] reported $\beta$-pinene, $\beta$-caryophyllene,

This is an open access journal, and articles are distributed under the terms of the Creative Commons Attribution-NonCommercial 4.0 International (CC BY-NC 4.0) License, which allows others to copy and redistribute the material in any medium or format, remix, transform, and build upon the material, as long as appropriate credit is given and the new creations are licensed under the identical terms. 
bicylogermacrene and $\beta$-pinene while Olonisakin et al. [21], revealed the presence of $\beta$-pinene, $\mathrm{D}$-limonene and caryophyllene as the major constituents of a different Nigerian sample of $P$. guineense.

Harvested plants parts in their fresh states are perishable in nature which may affect their usefulness in traditional medicine. The post-harvesting processes e.g. extraction and drying methods are of great concern because of their influences on the quality and quantity of the bioactive constituents of medicinal plants [22-25]. Specific emphasis on the role of sun-drying on aromatic plants in recent research has shown that it can induce chemical changes and consequently affect the bioactivity of plant extracts [26-28]. Reports have also shown that many medicinal plants in developing countries have failed to meet the quality standards for supply to the international market because of poor preservation techniques which affect quality [29].

As part of research efforts at public awareness and quality control, information on major constituents of essential oils from same plant but different treatment has become necessary. Thus the objective of this study was to ascertain the constituents and resultant chemotypes of Piper guineensis berries due to sun-drying. In addition, the comparative antimicrobial potential of essential oils from fresh and sun-dried Piper guineensis (Schum. and Thom.) seeds was investigated.

\section{EXPERIMENTAL}

Collection of plant material: Fresh berries of Piper guineense were purchased from a local herb seller at the main market, Akure, Ondo State, Nigeria. The acquired quantity was divided into two and one portion was sun dried for 3 weeks prior to extraction while the remainder was extracted directly. Drying was done to imitate local drying processes and 3 weeks was sufficient to give the desired dried quality defined by its pulverizability i.e. easy conversion to powder

Extraction of essential oils: The fresh and dried samples were grounded separately in a mortar and $350 \mathrm{~g}$ of pulverized samples were subjected to hydrodistillation separately in $1.5 \mathrm{~L}$ of distilled water using an all-glass Clevenger-type apparatus for $5 \mathrm{~h}$ at temperature between 60 and $80^{\circ} \mathrm{C}$. The essential oils obtained were dried over anhydrous sodium sulphate and collected in sealed glass vial and were kept in the refrigerator before chemical and antimicrobial analyses.

Identification of essential oils' constituents: Chemical analyses of the extracted oil were achieved through a PerkinElmer Auto System (HP 6890/ HP ChemStation Rev. A09.01 (1206) Software) gas chromatograph (GC) integrated with a flame ionization detection (FID) system. The column used was CP-Sil 5CB, $25 \mathrm{~m} \times 0.32 \mu \mathrm{m}, 0.12$ film thickness. The initial column temperature was set at $40^{\circ} \mathrm{C}$ for 2 min and increased to $200{ }^{\circ} \mathrm{C}$ at the rate of $5^{\circ} \mathrm{C} / \mathrm{min}$. The detector temperature was maintained at $300^{\circ} \mathrm{C}$. The injection type was a split mode system, volume injected was $0.1 \mu \mathrm{L}$ without dilution and hydrogen was the carrier gas set at the flow rate of $1.0 \mathrm{~mL} / \mathrm{min}$.

The GC/MS analyses were carried out on a Shimadzu GCMS (QP5050A) series. The capillary column type was (DB-5; $30.0 \mathrm{~m}$ (length) $\times 0.25 \mathrm{~mm}$ (diameter) $\times 0.25 \mu \mathrm{m}$ (film thickness). The carrier gas was helium at constant flow rate of 2 $\mathrm{mL} / \mathrm{min}$. The initial column temperature was $80^{\circ} \mathrm{C}$ held for 2 min and increased by $10^{\circ} \mathrm{C} / \mathrm{min}$ to a final temperature of $240{ }^{\circ} \mathrm{C}$ held for $6 \mathrm{~min}$. Sample injection volume was $1 \mu \mathrm{L}$. The spectrometric data were integrated using the automated mass spectral deconvolution and identification system (AMDIS) software. The essential oils constituents were identified by comparison of the mass spectral fragmentation profile of the sample with the NIST standard mass fragmentation data bank (NIST Mass Spectral Search Program for the NIST/EPA/NIH Mass Spectral Library, version 2002 to 2006) and data from literature [30].

Antimicrobial assay: Two bacteria and two fungi species were used for the antimicrobial studies which were carried out through a method described by Washington and Sutter [31], with little modification. The bacteria (which were clinical isolates) were Staphylococcus aureus and Escherichia coli while the fungi were Candida albicans and Aspergillus flavus.

Nutrient agar and sabouraud dextrose agar (SDA) [Oxford Laboratories, UK] were used for bacteria and fungi, respectively as growth medium. The agar was poured in sterile petri dishes and was allowed to solidify. Broth cultures of the microbes left for $24 \mathrm{~h}$ were used to seed the agar plates (one organism per plate). Cork borer was used to make holes of about $5 \mathrm{~mm}$ in diameter on the solid agar medium.

Each well was then filled with $0.2 \mathrm{~mL}$ of prepared essential oil solutions. The plates were incubated at $37^{\circ} \mathrm{C}$ for $24 \mathrm{~h}$ for bacteria and $25^{\circ} \mathrm{C}$ for $48 \mathrm{~h}$ for fungi. The zones of inhibition were measured at the end of incubation period. Antimicrobial test was conducted in triplicates and zones of inhibition $(\mathrm{mm})$ were expressed as the mean.

Minimum inhibitory concentration (MIC), which is defined as the lowest concentration of extract that inhibits the growth of the organisms, was determined for the essential oils against the tested bacteria; Staphylococcus aureus, Escherichia coli, as well as against the pathogenic fungi; Candida albicans and Aspergillus flavus [32]. Standard antibiotics (gentamycin and tioconazole) were used as control for bacteria and fungi, respectively.

\section{RESULTS AND DISCUSSION}

Chemical composition of essential oils: Distillation yield essential oils from both fresh and dried berries of $P$. guineense were obtained as a pale yellow liquid with a characteristic aromatic smell of piper plants. The oil yields were 1.10 and $1.42 \% \mathrm{v} / \mathrm{w}$ for fresh and dried berries, respectively thus the dried fruit possess higher concentration of essential oils. The yields of oils were higher compared to $0.45 \%$ reported by Oyedeji et al. [20]. The differences may be due to the method and duration of preservations [33-37]. Both essential oils had the characteristic sharp odour and peppery spicy smell of $P$. guineenses.

Monoterpene biosynthesis and accumulation in some plants have been reported to be specifically localized to the glandular trichomes [38,39] and the pathway originates in the plastids (leucoplasts) of the secretory cells of these highly specialized, non-photosynthetic glandular structures [40]. As such these monoterpene stores could be relieved of their content with decomposition of plant parts which causes gradual loss of cellular matrix. Reports have shown that the chemical composition of essential oils is often dependent on the conditions during 
processing and storage of the plant material, upon distillation as well as in the course of subsequent handling of the oil itself [41-47].

Although the chemical composition of essential oils from both fresh and dried Piper guineensis seeds agrees qualitatively with literature on main components i.e. terpenes such as $\beta$ pinene, limonene, $\beta$-caryophyllene, spathulenol, e-nerolidol, $\delta$-bicyclogermecrene and cadinol [10,20,21,48-50]. Both essential oils showed constituents which did not overlap and constituents with sharp elevated levels after drying. The occurrence of non-overlapping constituents suggests the formation of new terpenes from existing terpenes during sun-drying [51,52].

Sixty phytochemicals were identified by the GC/MS and GC/FID analyses as constituents of the essential oils. The components with their percentages are listed in Table-1. Comparative analysis of essential oils extracts from fresh Piper guineensis berries and sun-dried berries afforded different chemotypes. All major functional groups common to essential oils i.e. alkenes and alcohols were represented in both chemotypes in addition to esters and phenols in essential oils from fresh the berries.

Dried berries showed a higher percentage content of alcohols (13.89\%) compared to fresh berries $(10.23 \%)$. Both extracts had overlapping contents of alcohol terpenoids except for 2-hydroxy-1,8-cineole, cis-geraniol, cis-sabinol and trans-nerolidol which were exclusive to dried berrieswhile the sesquiterpene alcohol spathulenol was exclusive to fresh seeds (Table-1). A significantly higher increase of $\beta$-linalool was recorded in dried seeds $(11.96 \%)$ compared to fresh seeds $(9.3 \%)$.

Alkene monoterpenes were of a higher percentage composition in fresh seeds $(64.08 \%)$ compared to dried seeds (33.26 $\%$ ) while dried seeds had a higher percentage composition of sesquiterpene alkenes $(45.97 \%)$ compared to fresh seeds ( 25.32 $\%)$. Fresh and dried seeds had overlapping alkene monoterpene content except for 3-methyl apopinene and $\delta$-limonene which were exclusively present in dried seeds. Marked reduction in percentage composition of 3-carene (5.38\%) and $\alpha$-phellandrene $(2.79 \%)$ was observed in dried seeds compared to fresh seeds (16.63 and $26.32 \%$, respectively). Fresh and dried seeds also had overlapping contents of alkene sesquiterpenes except caryophyllene oxide, elixene, germacrene- $\mathrm{D}$, valencrene, $\alpha$ bergamoten and $\alpha$-guaiene which were exclusive to fresh seeds while cedrene, $\alpha$-bisabolene and $\beta$-copaene were exclusive to dried seeds. At least two fold increases in percentage $\beta$ bisabolene, $\beta$-farnesene, $\beta$-sesquiphellandrene, $\gamma$-elemene, $\gamma$ muurolene, $\delta$-cadinene copaene and $\beta$-elemene was recorded in dried seeds compared to fresh seeds.

Ketones, phenols and esters emerged as minor constituents of essential oil extracts from seeds of Piper guineensis. Fresh seeds had higher percentage composition of ketones $(0.49 \%)$ compared to dried seeds $(0.32 \%)$. Each group had differing ketone constituents with piperitone being the only overlapping ketone. Piperitone was three fold higher in fresh seeds $(0.29$ $\%)$ compared to dried seeds $(0.08 \%)$. Ketones i.e. camphor, isocamphinone, L-trans-pinocarveol were exclusive to dried seeds while cryptone and $p$-menth-6-en-2-one were exclusive to fresh seeds. The only phenol and ester constituent detected i.e. carvacrol and sabinyl acetate, respectively was only present in fresh seeds and not in dry seeds.
TABLE-1

CHEMICAL CONSTITUENTS OF THE ESSENTIAL OILS OF THE DRIED AND FRESH BERRIES OF Piper guineense

\begin{tabular}{|c|c|c|c|c|}
\hline \multirow{2}{*}{$\begin{array}{l}\text { S. } \\
\text { No. }\end{array}$} & \multirow[b]{2}{*}{ Chemical compound } & \multirow{2}{*}{$\begin{array}{l}\text { Retention } \\
\text { time (min) }\end{array}$} & \multicolumn{2}{|c|}{ Composition (\%) } \\
\hline & & & $\begin{array}{l}\text { Dried } \\
\text { seed }\end{array}$ & $\begin{array}{l}\text { Fresh } \\
\text { seed }\end{array}$ \\
\hline 1 & $\alpha$-Pinene & 5.16 & 7.11 & 7.00 \\
\hline 2 & $\beta$-Phellandrene & 5.76 & 0.63 & - \\
\hline 3 & $\beta$-Pinene & 5.87 & 7.82 & 9.89 \\
\hline 4 & $\beta$-Myrcene & 5.98 & 2.85 & - \\
\hline 5 & $\alpha$-Phellandrene & 6.30 & 2.79 & 26.32 \\
\hline 6 & $\beta$-Cymene & 6.58 & 1.29 & 3.13 \\
\hline 7 & D-Limonene & 6.66 & 2.62 & - \\
\hline 8 & 3-Methyl-apopinene & 6.71 & 4.23 & - \\
\hline 9 & 3-Carene & 6.74 & 5.38 & 16.63 \\
\hline 10 & $\beta$-Ocimene & 6.88 & 0.97 & 0.72 \\
\hline 11 & $\gamma$-Terpinene & 7.15 & 0.21 & 0.16 \\
\hline 12 & 4-Carene & 7.55 & 0.84 & 0.23 \\
\hline 13 & $\beta$-Linalool & 7.78 & 11.96 & 9.30 \\
\hline 14 & neo-allo-ocimene & 8.18 & 0.79 & 1.34 \\
\hline 15 & L-trans-pinocarveol & 8.45 & 0.08 & - \\
\hline 16 & Camphor & 8.55 & 0.10 & - \\
\hline 17 & Isoborneol & 8.79 & 0.19 & 0.14 \\
\hline 18 & L-Borneol & 8.92 & 0.17 & 0.11 \\
\hline 19 & Isocamphopinone & 8.98 & 0.06 & - \\
\hline 20 & 4-Terpineol & 9.05 & 0.19 & 0.36 \\
\hline 21 & Crypton & 9.14 & - & 0.13 \\
\hline 22 & $\alpha$-Terpineol & 9.25 & 0.24 & 0.29 \\
\hline 23 & cis-Sabinol & 9.36 & 0.12 & - \\
\hline 24 & Sabinyl acetate & 9.38 & - & 0.19 \\
\hline 25 & cis-Geraniol & 9.62 & 0.04 & - \\
\hline 26 & $\alpha$-Limonene iepoxide & 9.95 & 0.06 & - \\
\hline 27 & P-menth-6-en-2-one & 10.04 & - & 0.07 \\
\hline 28 & Piperitone & 10.11 & 0.08 & 0.29 \\
\hline 29 & Carvacrol & 10.69 & - & 0.07 \\
\hline 30 & 2-Hydroxy-1,8-cineole & 11.02 & 0.14 & - \\
\hline 31 & Elixene & 11.25 & - & 0.26 \\
\hline 32 & $\delta$-Elemene & 11.27 & 0.19 & - \\
\hline 33 & $\alpha$-Cubebene & 11.45 & 0.63 & 0.10 \\
\hline 34 & Ylangene & 11.79 & 0.29 & 0.12 \\
\hline 35 & Copaene & 11.88 & 4.34 & 0.62 \\
\hline 36 & $\beta$-Elemene & 12.03 & 4.35 & 1.99 \\
\hline 37 & $\delta$-Selinene & 12.31 & 0.69 & - \\
\hline 38 & $\alpha$-Bergamotene & 12.33 & - & 0.43 \\
\hline 39 & Caryophyllene & 12.50 & 7.65 & 7.27 \\
\hline 40 & $\gamma$-Elemene & 12.55 & 2.13 & 0.21 \\
\hline 41 & $\alpha$-Muurolene & 12.72 & 1.47 & - \\
\hline 42 & $\alpha$-Guaiene & 12.73 & - & 0.12 \\
\hline 43 & $\beta$-Farnesene & 12.77 & 2.07 & 0.35 \\
\hline 44 & Cedrene & 12.84 & 0.54 & - \\
\hline 45 & Humulene & 12.95 & 2.64 & 2.20 \\
\hline 46 & Valencrene & 13.15 & - & 1.38 \\
\hline 47 & $\gamma$-Muurolene & 13.16 & 1.59 & 0.17 \\
\hline 48 & Germacrene D & 13.26 & - & 1.38 \\
\hline 49 & $\beta$-Copaene & 13.28 & 4.16 & - \\
\hline 50 & $\beta$-Eudesmene & 13.39 & 2.41 & 2.82 \\
\hline 51 & $\alpha$-Selinene & 13.46 & 1.85 & 1.45 \\
\hline 52 & $\beta$-Bisabolene & 13.53 & 5.11 & 0.57 \\
\hline 53 & $\delta$-Cadinene & 13.69 & 0.93 & 0.19 \\
\hline 54 & $\beta$-Sesquiphellandrene & - & 2.32 & 0.35 \\
\hline 55 & $\alpha$-Patchoulene & 13.77 & 1.14 & 1.11 \\
\hline 56 & $\alpha$-Bisabolene & 13.90 & 0.43 & - \\
\hline 57 & Germacrene B & 14.12 & 0.60 & 0.76 \\
\hline 58 & trans-Nerolidol & 14.25 & 0.84 & - \\
\hline 59 & Spathulenol & 14.45 & - & 0.03 \\
\hline 60 & Caryophyllene oxide & - & 0.13 & - \\
\hline
\end{tabular}


The presence of germacrene-D in fresh berries and its absence in dried berries may be explained in relation to its role as an intermediate in the biosynthesis of sesquiterpenes from farnesyl diphosphate (FPP) via deprotonation and reprotonation processes. Antimicrobial Activities of the essential oils. The higher alcohol content of essential oils from sun-dried berries of $P$. guineensis may also be attributed to the open air drying method which can allow a larger surface area for air to oxidize terpenes within the already deteriorating matrix of the plant part. For instance, most compounds derived from terpene biosynthesis in wine grapes are actually terpenoids, which are terpenes or terpene alcohols (terpene synthases can produce alkenes via deprotonation or alcohols via water capture) that have undergone chemical transformation(s), typically oxidation (sometimes promoted by enzymes, sometimes not).

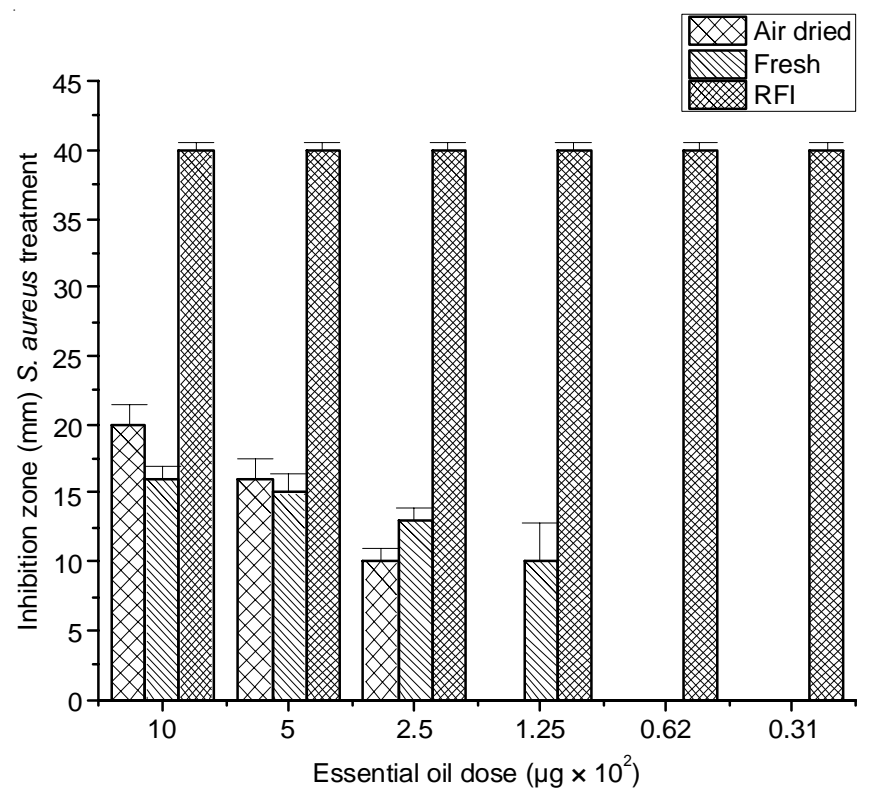

Antibacterial assay: The essential oils of the fresh and dried berries of Piper guineense (Schum. and Thom) were evaluated for antimicrobial activities against pathogenic strains of Gram-positive bacteria (Staphylococcus aureus) and Gramnegative bacteria (Escherichia coli). Two fungi species: Candida albicans and Aspergillus flavus (Figs. 1 and 2).

Antimicrobial activity of essential oil from dried berries was obvious at higher concentrations $\left(2.5-10 \mu \mathrm{g} \times 10^{2}\right)$ when introduced to Gram-positive bacteria (S. aureus) while essential oil from fresh berries showed more significant antimicrobial activity than oils from dried berries at lower concentrations $\left(1.25-2.50 \mu \mathrm{g} \times 10^{2}\right)$. For assay with gram negative microbes (E. coli) no bioactivity was observed for essential oil of dried seeds at lower concentrations $\left(0.31-1.25 \mu \mathrm{g} \times 10^{2}\right)$ only at higher concentrations between $2.5-10 \mu \mathrm{g} \times 10^{2}$. Bioactivity of essential

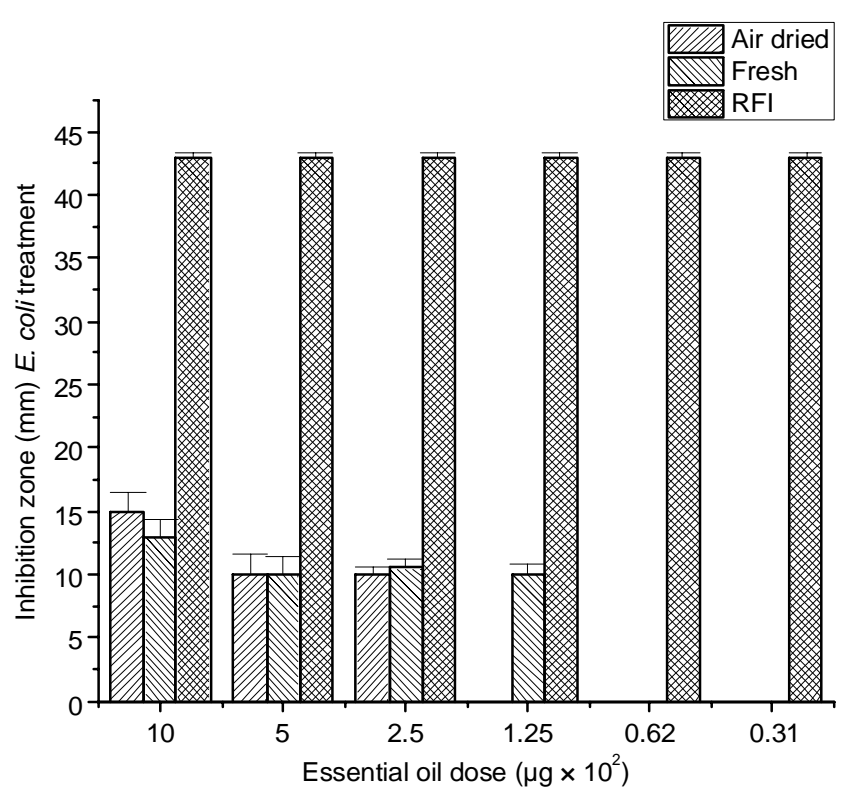

Fig. 1. Antimicrobial activity of the essential oil of the dried and fresh berries of Piper guineense (Schum and Thom), where RFI $=$ reference inhibitor antimicrobial test RFI $=$ Gentamycin $(10 \mu \mathrm{g} / \mathrm{mL})$
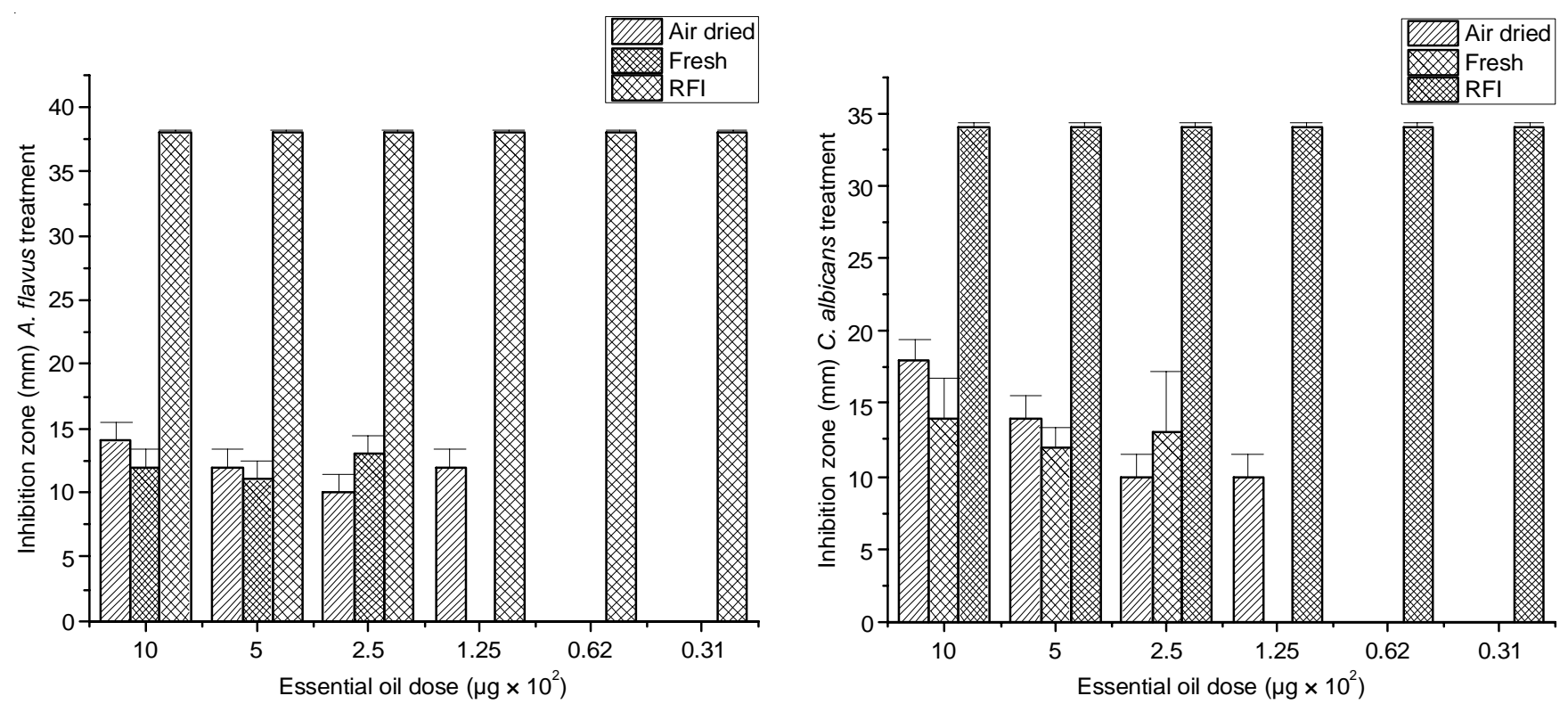

Fig. 2. Antifungal activity of the essential oil of the dried and fresh berries of Piper guineense (Schum and Thom), where RFI $=$ reference inhibitor antifungal test RFI $=$ tioconazole $(70 \%)$ 
oil from fresh extracts was more potent than oils from dried berries at lower concentrations with decreasing potency as higher concentrations were introduced into the assay. In essence bioactivity of essential oils against gram-positive bacteria showed fresh berries had a lower MIC $\left(1.25 \mu \mathrm{g} \times 10^{2}\right)$ compared to dried berries with an MIC of 2.5-10 $\mu \mathrm{g} \times 10^{2}$.

The antimicrobial activity of essential oils from dried and fresh berries against gram negative bacteria showed a similar trend except essential oils were slightly less potent against Gram-negative bacteria compared to bioactivity exhibited against Gram-positive bacteria. The fresh and dried berries of Piper guineense essential oils were active against all the microbes but were at least 2-fold and 3-fold less potent against Gram positive and Gram-negative bacteria, respectively compared to the reference inhibitor i.e. gentamycin and tioconazole (Figs. 1 and 2). The essential oils were more effective within the concentration range of $1000.0-250.0 \mu \mathrm{g} / \mathrm{mL}$ against the four tested organism. In essence bioactivity of essential oils against Gram-negative bacteria showed that oils from fresh berries had a lower MIC $\left(1.25 \mu \mathrm{g} \times 10^{2}\right)$ compared to dried berries with an MIC of $2.5-10 \mu \mathrm{g} \times 10^{2}$.

Antifungal assay: Antifungal assay using pathogenic fungi A. flavus showed that essential oils from dried seeds showed a minimal inhibition concentration of $1.25 \mu \mathrm{g} \times 10^{2}$ while essential oils from fresh seeds showed a minimal inhibition concentration (MIC) of $2.5 \mu \mathrm{g} \times 10^{2}$. Highest inhibition was achieved with essential oils from dried seeds compared to oils from fresh seeds. A clear concentration dependent antimicrobial activity was not observed for this assay.

Antifungal assay using C. albicans showed essential oils from dried seeds having an MIC of $1.25 \mu \mathrm{g} \times 10^{2}$, while oils from fresh seeds showed MIC of $2.5 \mu \mathrm{g} \times 10^{2}$. Highest inhibition was achieved with essential oils from dried seeds compared to oils from fresh seeds and strong concentration dependent inhibition was observed for oils from dried seeds compared to oils from fresh seeds.

In general, bioactivity of essential oil from both dried and fresh berries were about 2 -fold and 3 -fold less potent than the reference inhibitor tioconazole.

\section{Conclusion}

This study has established marked differences in the chemical constituents of the essential oils of sun-dried and fresh berries of Piper guineense (Schum. and Thom). Although the essential oil from dried berries was slightly more active against tested organisms compared to the essential oil from the fresh berries, the lower MIC for oils from fresh berries against gram positive and gram negative bacteria may suggest a higher clinical relevance over oils from dried berries. Alternatively, the lower MIC for oils from dried berries against the two pathogenic fungi suggests its clinical suitability over oils from fresh berries. The varied concentration depended antimicrobial activity of both oils across various microorganisms used in this study suggests that essential oils may be specific for particular organisms, species and strains depending on the major terpene constituent of the botanical. Furthermore, sun-drying appeared to enhance the aromatic and antimicrobial quality of essential oils from Piper guineensis.

\section{CONFLICT OF INTEREST}

The authors declare that there is no conflict of interests regarding the publication of this article.

\section{REFERENCES}

1. A. Djilani and A. Dicko, ed.: J. Bouayed, The Therapeutic Benefits of Essential Oils, Nutrition, Well- Being and Health, p. 160 (2012)

2. P.S.X. Yap, T. Krishnan, B.C. Yiap, C.P. Hu, K.G. Chan and S.H.E. Lim, J. Appl. Microbiol., 116, 1119 (2014);

https://doi.org/10.1111/jam.12444.

3. P.S.X. Yap, B.C. Yiap, H.C. Ping and S.H.E. Lim, Open Microbiol. J. 8, 6 (2014); https://doi.org/10.2174/1874285801408010006.

4. E. Heuberger, How Does the Route of Administration Affect the Efficacy of Essential Oils? Bulletin Technique Gattefossé No. 103: Aromatherapy: Is There a Role for Essential Oils in Current and Future Healthcare? pp. 71-80 (2010).

5. W. Dhifi, S. Bellili, S. Jazi, N. Bahloul and W. Mnif, Medicines (Basel), 3, 25 (2016);

https://doi.org/10.3390/medicines3040025.

6. S. Burt, Int. J. Food Microbiol., 94, 223 (2004); https://doi.org/10.1016/j.ijfoodmicro.2004.03.022.

7. Saba, A. Bernard and O.A. Tomori, Pak. J. Nutr., 6, 366 (2007).

8. S. Sengupta and A.B. Ray, Fitoterapia, 58, 147 (1987).

9. M.A. Isawumi, Niger. Field, 49, 37 (1984).

10. M.S. Owolabi and A. Oladipupo, Am. J. Essen. Oils Nat. Prod., 1, 37 (2013).

11. U.N. Onwuka and U.N. Nwosuagwu, Nig. Food J., 23, 74 (2005).

12. F.V. Udoh, Y.L. Theodore and V.B. Braide, Phytother. Res., 13, 106 (1999); https://doi.org/10.1002/(SICI)1099-1573(199903)13:2<106::AIDPTR362>3.0.CO;2-2.

13. S.C. Achinewhu, C.C. Ogbonna and A.D. Hart, Chemical Composition of Indigenous Wild Herbs, Spices, Fruits, Nuts and Leafy Vegetables Used as Foods. Plant Food for Human Nutrition, Kluwer Academic Publishers: Netherlands, vol. 48, pp. 341-388 (1995).

14. M.G. Miguel, Molecules, 15, 9252 (2010); https://doi.org/10.3390/molecules 15129252.

15. W.N. Setzer, G. Park, B.R. Agius, S.L. Stokes, T.M. Walker and W.A. Haber, Natural Prod. Commun., 3, 1367 (2008).

16. D.F. Moura do Carmo, A.C.F. Amaral, G.M.C. Machado, L.L. Leon and J.R.A. Silva, Molecules, 17, 1819 (2012); https://doi.org/10.3390/molecules 17021819.

17. C.J. Muller and W.G. Jennings, J. Agric. Food Chem., 15, 762 (1967); https://doi.org/10.1021/jf60153a001.

18. E.U. Okonkwo and W.I. Okoye, Int. J. Pest Manage., 42, 143 (1996); https://doi.org/10.1080/09670879609371985.

19. N.E.S. Lale, Post Harvest News Information, 6, 69 (1995).

20. A.O. Oyedeji, B.A. Adeniyi, O. Ajayi and W.A. Konig, Phytother. Res., 19, 362 (2005); https://doi.org/10.1002/ptr.1679.

21. A. Olonisakin, M.O. Oladimeji and L. Lajide, J. Appl. Sci. (Faisalabad), 6, 2520 (2006); https://doi.org/10.3923/jas.2006.2520.2522.

22. O.M. Wahab, Botany Res. Int., 8, 77 (2015); https://doi.org/10.5829/idosi.bri.2015.8.4.12823.

23. H. Olsen, K. Aaby and G.I.A. Borge, J. Agric. Food Chem., 57, 2816 (2009); https://doi.org/10.1021/if803693t.

24. F. Anwar, U. Kalsoom, B. Sultana, M. Mushtaq, T. Mehmood and H.A. Arshad, Int. Food Res. J., 20, 653 (2013).

25. T.H. Katamssadan, Int. J. Biosci., 7, 135 (2015); https://doi.org/10.12692/ijb/7.2.135-151.

26. A.R. Mohamed Hanaa, Y.I. Sallam, A.S. El-Leithy and E.A. Safaa, Annals Agric. Sci., 57, 113 (2012).

27. S. Najafian and M. Agah, Eur. J. Exp. Biol., 2, 1771 (2012).

28. R. Shahhoseini, A. Estaji, N. Hosseini, M. Ghorbanpour and R. Omidbaigi, J. Essent. Oils Bearing Plants, 16, 474 (2013); https://doi.org/10.1080/0972060X.2013.813270. 
29. R.P. Rocha, E. de Castro Melo, J.A. Demuner, L.L. Radünz and B.J. José Bon Corbín, Afr. J. Food Sci. Technol., 2, 132 (2011).

30. R.P. Adams, Identification of Essential Oil Components by Gas Chromatography/Mass Spectroscopy, Allured Publishing Corporation: Illinois, USA, pp. 5-115 (1995).

31. J.A. Washington II and V.L. Sutter, Dilution Susceptibility Test: Agar and Macro-Broth Dilution Procedure, In: Mannual of Clinical Microbiology, American Society for Microbiology: Washington D.C., edn 3 (1980).

32. A. Janssen, J. Scheffer and A. Svendsen, Planta Med., 53, 395 (1987); https://doi.org/10.1055/s-2006-962755.

33. K.-H. Kubeczka, History and Sources of Essential Oil Research, In: Handbook of Essential Oils: Science, Technology and Applications (1993).

34. R.P.W. Scott, eds.: P. Worsfold, A. Townshend A and C. Poole, Encyclopedia of Analytical Science, Elsevier: Amsterdam, London, New York, edn 2, pp. 554-561 (2005)

35. B.D. Saffron, Acta Hortic., 89 (1993).

36. S.G. Deans and K.P. Svoboda, Acta Hortic., 450 (1992); https://doi.org/10.17660/ActaHortic.1992.306.60.

37. D.A. Moyler, ed: G. Charalambous, Spices - Recent Advances. In: Spices, herbs and Edible Fungi, Elsevier Science B.V.: Amsterdam, The Netherlands pp. 1-70 (1994).

38. J. Gershenzon, M. Maffei and R. Croteau, Plant Physiol., 89, 1351 (1989); https://doi.org/10.1104/pp.89.4.1351.

39. D.G. McCaskill, J. Gershenzon and R. Croteau, Planta, 187, 445 (1992); https://doi.org/10.1007/BF00199962.

40. G. Turner, J. Gershenzon, E.E. Nielson, J.E. Froehlich and R. Croteau, Plant Physiol., 120, 879 (1999); https://doi.org/10.1104/pp.120.3.879.
41. G. Schmaus and K.-H. Kubeczka, eds.: S.A. Baerheim and J.J.C. Scheffer, The Influence of Isolation Conditions on the Composition of Essential Oils Containing Linalool and Linalyl Acetate, In: Essential Oils and Aromatic Plants, Martinus Nijhoff/Dr W. Junk Publishers: Dordrecht, Germany, pp. 127-134 (1985).

42. R. Carle and I. Fleischhauer, Dtsch. Apoth. Ztg., 127, 2451 (1987).

43. N. Fischer, S. Nitz and F. Drawert, J. Agric. Food Chem., 36, 996 (1988); https://doi.org/10.1021/jf00083a023.

44. O. Baritaux, H. Richard, J. Touche and M. Derbesy, Flav. Fragr. J., 7, 267 (1992); https://doi.org/10.1002/ffj.2730070507.

45. R. Venskutonis, L. Poll and M. Larsen, Flav. Fragr. J., 11, 123 (1996); https://doi.org/10.1002/(SICI)1099-1026(199603)11:2<123::AIDFFJ555>3.0.CO:2-1

46. D. Mockutë, G. Bernotienë and A. Judpentienë, Chemija, 16, 29 (2005);

47. U. Schweiggert, R. Carle and A. Schieber, Trends Food Sci. Technol., 18, 260 (2007); https://doi.org/10.1016/j.tifs.2007.01.005.

48. P.R.D. Santos, D.L. Moreira, E.F. Guimaraes and M.A.C. Kaplan, Phytochemistry, 58, 547 (2001); https://doi.org/10.1016/S0031-9422(01)00290-4.

49. A. Guerrini, G. Sacchetti, D. Rossi, G. Paganetto, M. Muzzoli, E. Andreotti, M. Tognolini, M.E. Maldonado and R. Bruni, Environ. Toxicol. Pharmacol., 27, 39 (2009); https://doi.org/10.1016/j.etap.2008.08.002.

50. J.G.S. Maia and E.H.A. Andrade, Quim. Nova, 32, 595 (2009); https://doi.org/10.1590/S0100-40422009000300006.

51. D.W. Christianson, Chem. Rev., 106, 3412 (2006); https://doi.org/10.1021/cr050286w.

52. D.J. Tantillo, Nat. Prod. Rep., 28, 1035 (2011); https://doi.org/10.1039/c1np00006c. 